\title{
Effects of Detergents on Activity, Thermostability and Aggregation of Two Alkalithermophilic Lipases from Thermosyntropha lipolytica
}

\author{
Moh'd A. Salameh" ${ }^{\#}$ and Juergen Wiegel*
}

Department of Microbiology, University of Georgia, Athens, Georgia 30602-2605, USA

\begin{abstract}
Thermosyntropha lipolytica DSM 11003, an anaerobic thermophilic lipolytic bacterium, produces the two alkalithermophilic lipases, LipA and LipB. Among all tested detergents, the two lipases were mostly affected by SDS when used at concentrations below its critical micelle concentration (CMC). In the absence of SDS, the $v_{\max }$ of both LipA and LipB were $12.6 \mathrm{U} \cdot \mathrm{mg}^{-1}$ and $13.3 \mathrm{U} \cdot \mathrm{mg}^{-1}$ and $\mathrm{K}_{0.5}$ were $1.8 \mathrm{mM}$ and $1.65 \mathrm{mM}$, respectively at $96^{\circ} \mathrm{C}$ and $\mathrm{pH}_{\mathrm{opt}}{ }^{25^{\circ} \mathrm{C}} \mathrm{of} 9.4-$ 9.6. In the presence of $0.2 \%$ SDS, the $v_{\max }$ increased to $105 \mathrm{U} \cdot \mathrm{mg}^{-1}$ and $112 \mathrm{U} \cdot \mathrm{mg}^{-1}$, and $\mathrm{K}_{0.5}$ values decreased to $200 \mu \mathrm{M}$ and $140 \mu \mathrm{M}$ for LipA and LipB, respectively. Inhibitory assays of lipases using diisopropyl p-nitrophenylphosphate (E600) with increasing concentration of SDS and Tween 20 strongly suggest that SDS and Tween 20 do bind to the lid domain and/or active site pocket, thus promoting conformational changes that facilitate active site accessibility for the substrate. The two lipases exhibited moderate activation in the presence of nonionic detergents when used below their CMC values. Both lipases were found to exhibit strong tendency to aggregate as observed through gel filtration chromatography and gradient native gel electrophoresis. The addition of $1.0 \%$ (w/v) SDS led to disaggregation as the lipases were eluted corresponding to their monomeric mass (based on SDS gel electrophoresis value) and caused a significant decrease in thermostability, suggesting that, enzyme aggregation might be a major contributor to the high thermostability of LipA and LipB.
\end{abstract}

Keywords: Thermosyntropha lipolytica, Lipases, aggregation/oligomerization, Alkalithermophilic, SDS; non ionic- anionicand cationic detergents.

\section{INTRODUCTION}

Lipases (E.C. 3.1.1.3) are activated at the water-lipid interface; they show little activity when the substrate is in the monomeric form and activity increases dramatically above the substrate solubility limit, where they start to form emulsions [1, 2]. This response is currently known as interfacial activation [2, 3].

Lipases are ubiquitous and versatile enzymes, because of their ability to catalyze hydrolysis and synthesis of esterification reactions; they are used in many industrial applications including pharmaceutical, dairy, detergent, cosmetic, oleochemical, fat processing and many others [48]. For a lipase to be useful as a detergent additive, it should be alkaliphilic, thermostable, resistant to denaturation, and active in the presence of detergent. Enzymes from thermophilic organisms are generally more robust, more thermo- and detergent-stable, and active at elevated temperatures [9-12].

Triton X-100, Tween 20 and Tween 80 are nonionic polyoxyethylene detergents and in aqueous solutions form two phases upon temperature increase: a detergent-enriched also called coacervate phase and a detergent-depleted phase [13]. Terstappen et al. [14] found that there is a positive

\footnotetext{
*Address correspondence to this author at the Dept. of Microbiology, University of Georgia, 1000 Cedar Street, Biological Sciences Bldg. Rm 211-212C, Athens GA 30602-2605, USA; Tel/Fax: (706) 542 2651; E-mail: jwiegel@uga.edu

${ }^{\#}$ Present Address: Cancer Research Center, Mayo Clinic, Jacksonville, FL 32224; Tel: (904) 953 0046; E-mail: salameh.mohd@mayo.edu
}

correlation between protein hydrophobicity and its partitioning into the coacervate phase which confirmed that protein-detergent interactions in such systems are mainly hydrophobic. Lipases generally exhibit high content of hydrophobic amino acids which can lead to protein aggregation. Several lipases were found to form aggregation, most noticeably are the lipases from Burkholderia (bas Pseudomonas) cepacia [15], Geobacillus (bas Bacillus) thermocatenulatus (BTL2) [16], rice bran (Oryza sativa) [17], B. subtilis [18], and most interestingly the lipases from four strains of the psychrotolerant Moraxella sp. are also secreted in large aggregates $(\sim 400 \mathrm{kDa})[19]$. At this time, it is unclear whether these interactions are generally aggregates or could also be true biochemically defined oligomerizations.

Previously, we reported on the purification and characterization of two constitutively formed, highly thermophilic lipases, LipA and LipB [20]. They are the most thermophilic and thermostable lipases reported so far: maximum catalytic activity observed at $96^{\circ} \mathrm{C}$, and optimum $\mathrm{pH}^{80^{\circ} \mathrm{C}}$ (for explanation of $\mathrm{pH}$ notation for alkaline $\mathrm{pH}$ at elevated temperatures see [28]) around 8.5, and a $24 \mathrm{~h}$ half life temperature of $75^{\circ} \mathrm{C}$. In a recent report, these lipases were further proved to be very robust and resistant to denaturation as they successfully catalyzed the synthesis of various fatty acid alcohol esters in isooctane at $90^{\circ} \mathrm{C}$ [21]. Here, we describe and discuss effects of different detergents on the enzymatic activity, thermal stability and structural implications. We also report that the high thermostability of both enzymes is acquired by their aggregation / oligomerization state. 


\section{MATERIALS AND METHODS}

\section{Lipases Production and Purification}

Thermosyntropha lipolytica was grown in a basal medium containing $0.75 \%$ yeast extract as carbon and energy sources under nitrogen gas phase. Culture conditions, purification, and lipase assays using the chromogenic substrate $p$-nitrophenyl laurate ( $p$ NPL) (Sigma, USA) [22], were conducted essentially as described previously [20,21]. Protein concentrations were routinely determined with the bicinchoninic acid (BCA) protein assay kit (Pierce). SDS/PAGE and non denaturing PAGE were performed as described by Sambrook and Ausubel [23, 24].

\section{Determination of Critical Micelle Concentration (CMC) Under Test Conditions}

All tested detergents were from Sigma, and included the anionic detergents sodium dodecyl sulfate (SDS) and sodium cholate, the cationic detergents hexadecyltrimethylammonium bromide (CTAB), and the non ionic detergents toctylphenoxypolyethoxyethanol (Triton X-100), polyoxyethylene sorbitan monolaurate (Tween 20) and polyoxyethylene sorbitan monooleate (Tween 80 ). The CMC values of detergents were determined using the fluorescence properties of $N$-phenyl-1-naphthylamine (NPN) (Sigma) as described elsewhere [25-27]. Basically, in aqueous solution NPN has a low fluorescence quantum; however, the partitioning of NPN into an apolar environment such as micelles is associated with a dramatic increase in the fluorescence intensity. Detergents were suspended in the assay buffer at room temperature at varying concentrations $(1 \mu \mathrm{M}$ to $25 \mathrm{mM})$ and then incubated for $1 \mathrm{~h}$ in the presence of $10 \mu \mathrm{M} \mathrm{NPN}$ at $50^{\circ} \mathrm{C}$. The fluorescence intensity was measured using a computerized fluorometer (Shimadzu RF$5301 \mathrm{PC})\left(\lambda_{\mathrm{ex}}=350 \mathrm{~nm}, \lambda_{\mathrm{em}}=435 \mathrm{~nm}, 1 \mathrm{~nm}\right.$ bandwidth$)$. When plotting NPN fluorescence as a function of detergent concentration, the CMC was determined from the breakpoint of the curve.

\section{Determination of Enzymatic Activity in the Presence of SDS}

The temperature and $\mathrm{pH}$ optima for maximum catalytic activity of LipA and LipB were previously determined along with a thermostability study [20]. A temperature gradient incubator was used to determine the temperature activity profiles of both enzymes in the presence of $0.2 \%$ SDS, the concentration at which maximum catalytic activity was observed. The enzyme assays were conducted as described previously [15]. The assay buffer was adjusted at $\mathrm{pH}^{25^{\circ} \mathrm{C}} 9.4$ and 9.6 which are equivalent to $\mathrm{pH}^{80^{\circ} \mathrm{C}} 8.5$ and 8.8 for LipA and LipB, respectively, i.e., when the $\mathrm{pH}$ was measured at $80^{\circ} \mathrm{C}$ and the electrode and $\mathrm{pH}$-meter were calibrated at $80^{\circ} \mathrm{C}$ [28]. The substrate and SDS were pre-equilibrated in the assay reaction for $3 \mathrm{~min}$ prior to enzyme addition, after which the reaction was proceeded for $15 \mathrm{~min}$. Assays were conducted in triplicates and were always corrected for the reading of control assays missing the addition of enzyme.

\section{The Effect of Various Detergents on Activity and Stability}

The standard assay, as described earlier, was employed with increasing concentration of detergent. The enzymatic assays temperature was $92^{\circ} \mathrm{C}$, which was a compromise between lipase activity and substrate stability in the presence of detergent. To measure the lipases residual activities after the incubation with detergents, we set up parallel experiments where aliquots of purified LipA and LipB were each incubated in the presence of $1 \%$ SDS and $1 \%$ Tween 20 in sealed $2 \mathrm{ml}$ serum bottles. Each time point bottle contained $50 \mu \mathrm{g}$ of pure enzyme in $0.6 \mathrm{ml}$ of $100 \mathrm{mM}$ Tris buffer, $\mathrm{pH} 8.0$ and $0.5 \mathrm{M}$ ammonium sulfate. After incubation, the samples were concentrated and desalted by using $10 \mathrm{kDa}$ cut off Centricon filter tubes (Millipore, USA), protein quantified and assayed for lipase activity. Each time point was conducted in triplicate.

\section{Inhibition of LipA and LipB by Diisopropyl p- Nitrophenylphosphate (E600)}

Enzymatic activity experiments in the presence of the inhibitor E600 (Sigma, USA) were performed as described previously $[25,29]$ with the following modification; A 300 $\mathrm{nM}$ of either LipA and LipB, $5 \mathrm{mM}$ E600, and increasing concentrations of SDS and Tween 80 were all incubated in $100 \mathrm{mM}$ TAPS buffer $\mathrm{pH} 9.0(300 \mu \mathrm{l}$ final volume $)$ at $50^{\circ} \mathrm{C}$ for $120 \mathrm{~min}$, then proceeded by conducting enzyme assays as described above. Controls were carried out without E600, and all reactions were conducted in triplicates.

\section{RESULTS AND DISCUSSION}

\section{Effect of Detergents on Catalytic Activity}

Detergents in general have close resemblance to lipase substrates, i.e., when exceeding their solubility concentrations they form micelles. Different detergents will

Table 1. Properties of Various Detergents

\begin{tabular}{|c|c|c|c|c|c|}
\hline Detergent & MW & Class & $\mathrm{CMC}(\mathbf{m M})^{*_{\mathrm{a}}}$ & $\mathrm{CMC}(\mathrm{mM})^{\mathrm{b}}$ & $\mathrm{CMC}(\mathrm{mM})^{\mathrm{c}}$ \\
\hline Tween 20 & 1228 (avg) & Nonionic & 0.06 & 0.066 & 0.058 \\
\hline Tween 80 & 1310 (avg) & Nonionic & 0.01 & 0.014 & 0.01 \\
\hline СТАВ & 364 & Cationic & 0.92 & 1.1 & 0.9 \\
\hline Na cholate & 430.5 & Anionic & 14.0 & 14.6 & 14.6 \\
\hline
\end{tabular}

"The error on the CMC determinations is $10 \%$.

${ }^{a}$ Literature values [35].

${ }^{\mathrm{b}}$ Measured in $100 \mathrm{mM}$ TAPS $\mathrm{pH} 9.0$.

${ }^{c}$ Measured in $100 \mathrm{mM}$ TAPS pH 9.0 and $3 \mathrm{mM} p \mathrm{NPL}$. 
influence lipase activity differently. Substrate and detergent interactions with lipases can be complex and unpredictable $[25,29-31]$. There have been a few studies involving the effect of detergents on lipase activity [20, 32, 33]. However, all these studies used $p$-nitrophenyl butyrate as substrate which is a common substrate for esterases. As far as the authors are aware of, this is the first study that involves thermophilic lipases and the long chain fatty acid derivative $p$-nitrophenyl laurate.

Among all tested detergents, SDS was found to have the greatest impact on catalytic activity of both lipases (Fig. 1A). The effect of SDS on activity started at pre-micellar concentration of $1 \mathrm{mM}$, but the activity was only $3-6 \mathrm{U} \cdot \mathrm{mg}^{-1}$ higher than when tested in buffer alone. The activity drastically increased at around $2 \mathrm{mM}$, the CMC point (Table 1) and peaked at $7 \mathrm{mM}(0.2 \%)$ SDS, yielding an activity of 105 and $112 \mathrm{U} \cdot \mathrm{mg}^{-1}$ for LipA and LipB, respectively. At higher SDS concentrations, the activity declined to $4.5 \mathrm{U} \cdot \mathrm{mg}^{-1}$ and $10.6 \mathrm{U} \cdot \mathrm{mg}^{-1}$ for LipA and LipB, respectively. This result suggests that LipA was (partially) unfolded by SDS, whereas LipB was slightly more resistant to denaturation by elevated concentrations of SDS. The other ionic detergent, sodium cholate, showed a modest activity increase indicating that SDS binding is more effective (Fig. 1B). The cationic detergent CTAB was inhibitory to both lipases (Fig. 1C), which could be attributed to unfavorable electrostatic interactions that might cause unfolding and/or disrupt substrate binding [34]. A similar behavior was seen in Thermomyces lanuginosus lipase (TIL) [25], which was activated by SDS around the CMC level but then the activity

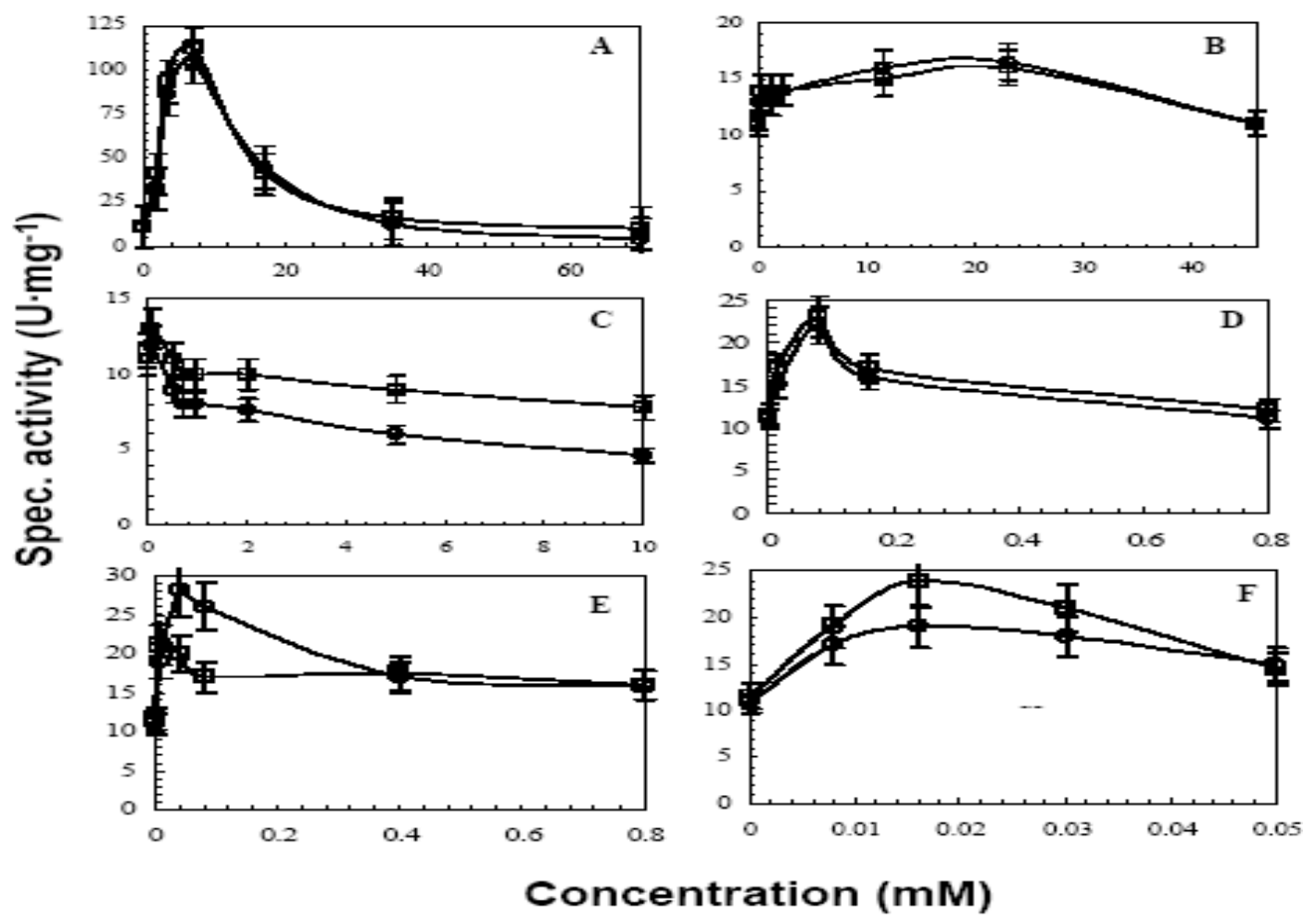

Fig. (1). Effects of various detergents on the activity of LipA ( $\odot$ ) and LipB ( $\square$ ). Increasing concentrations of the following detergents were used; SDS (A), Na cholate (B), CTAB (C), Triton X-100 (D), Tween $20(\mathbf{E})$ and Tween $80(\mathbf{F})$. Assays were carried out as described in the materials and methods section with some modifications. The assay buffer was $100 \mathrm{mM}$ TAPS adjusted at $\mathrm{pH}^{25{ }^{\circ} \mathrm{C}} 9.0$. The assay temperature was $92^{\circ} \mathrm{C}$. Non ionic detergents at concentrations higher than their CMC values caused turbidity in the assay solution, thus, assays were centrifuged and diluted before measuring the absorption.

declined above the CMC level. However, the activation to a100-fold increase at the detergent's CMC level and a decrease to only a 10-fold increase in comparison to the no detergent level was significantly more extensive than the observed effect for LipA and LipB.

The non ionic detergents, Triton X-100, Tween 20, and Tween 80 , slightly activated the lipases at concentration below their CMC levels (Table 1; Fig. 1D, E, F), followed by a gradual decline in activity to a plateau that is similar to the one without added detergent.

The activity profiles of non ionic detergents and SDS are similar based on the fact that the activation started at low concentrations below their CMC values and therefore does not involve micelles, but maximal activation as well as inhibition occurred in the presence of micelles. Similar results were also observed by others $[25,26]$. The possible explanation for these results is that SDS micelles bind preferably to the lid and activate the enzyme by triggering conformational changes, and that detergent binding and substrate binding are distinct. This conclusion is supported by other studies using fluorescence and X-ray crystallography which showed that micelles indeed bind to the lid that covers the active site and promote conformational changes $[25,29,36,37]$.

\section{SDS and Tween 20 Promote Conformational Changes}

To examine whether the binding of the detergent micelles do indeed trigger conformational changes, the covalently binding serine inhibitor diisopropyl $p$-nitrophenylphosphate 
Table 2. The Effect of E600 on LipA and LipB Activity in the Presence of SDS and Tween 20

\begin{tabular}{|c|c|c|c|c|}
\hline [SDS] & $\operatorname{LipA}^{\mathrm{a}}\left(\mathbf{U} \cdot \mathbf{m g}^{-1}\right)$ & $\operatorname{LipA}+\mathbf{E} 600\left(\mathbf{U} \cdot \mathrm{mg}^{-1}\right)$ & $\operatorname{LipB}^{\mathrm{b}}\left(\mathbf{U} \cdot \mathbf{m g}^{-1}\right)$ & $\mathrm{LipB}+\operatorname{E600}\left(\mathbf{U} \cdot \mathrm{mg}^{-1}\right)$ \\
\hline $3 \mathrm{mM}$ & $7.8 \pm 2.0$ & $2.0 \pm 1.0$ & $8.4 \pm 2.0$ & $2.3 \pm 1.0$ \\
\hline $7 \mathrm{mM}$ & $8.0 \pm 2.0$ & $3.0 \pm 1.4$ & $8.5 \pm 2.0$ & $1.6 \pm 1.4$ \\
\hline 0 & $11.6 \pm 0.5$ & $9.6 \pm 1.0$ & $12.4 \pm 0.5$ & $9.0 \pm 1.0$ \\
\hline $0.008 \mathrm{mM}$ & $10.0 \pm 1.2$ & $5.0 \pm 1.4$ & $9.5 \pm 1.6$ & $5.4 \pm 1.5$ \\
\hline $0.01 \mathrm{mM}$ & $9.0 \pm 2.0$ & $3.0 \pm 2.0$ & $9.2 \pm 2.0$ & $1.0 \pm 0.5$ \\
\hline $0.04 \mathrm{mM}$ & $7.6 \pm 1.2$ & $3.4 \pm 1.6$ & $7.0 \pm 1.4$ & $1.8 \pm 1.4$ \\
\hline
\end{tabular}

${ }^{\mathrm{a}}$ In the absence of detergents, LipA and LipB retained $90 \%$ activity after incubation at $60^{\circ} \mathrm{C}$ for $3 \mathrm{~h}$.

${ }^{\mathrm{b}} \mathrm{LipA}$ and LipB specific activities before incubation were 12.4 and $13.0 \mathrm{U} \cdot \mathrm{mg}^{-1}$, respectively.

(E600) assay was employed [38]. Serine in the active center is a required amino acid for activity, thus a modification of it will cause enzyme inhibition. E600 has access to the active site only when the enzyme is in the open conformation. E600 inhibited both lipases LipA and LipB in the presence of SDS micelles (Table 2). This indicates that the binding of the detergent micelles promote conformational changes that resembles the action of actual substrate micelles, i.e., exposing the active site for binding of E600 [25, 29]. In contrast to SDS, the presence of the non-ionic detergent, Tween 20 yielded maximum inhibition by E600 at concentration below and near the CMC limit. This suggests that Tween 20 monomers and not the micelles are more effective in binding to the enzymes and promoting conformational changes (Table 2). Hermoso et al. showed by means of crystallography that a non ionic detergent activated the porcine lipase and bound tightly to the active site pocket, acting like a substrate analog, but inhibition occurred at submicellar detergent concentration [29].

The major interactions between detergents and lipases are hydrophobic. However, the charged groups of cationic and anionic detergents play an important contribution to this interaction, therefore a considerable divergence on the behavior of cationic, anionic and as well as nonionic detergents with lipases could be seen [30]. It is proposed that the reason LipA and Lip B are not completely inhibited is due to a rigid confirmation of the highly thermostable and thermophilic enzymes [20], preventing total inhibition (Table 2).

\section{Substrate Hydrolysis Rates}

The hydrolysis rates of $p$-nitrophenyl laurate in the absence and presence of SDS were elucidated (Fig. 2). All substrate saturation curves were sigmoidal, i. e., when the substrate exceeded its solubility limit, the hydrolysis rate increased non hyperbolically. These results suggest that LipA and LipB are true lipases that show little activity toward soluble substrates and are interfacially activated by the micelles formed by $p$ NPL. The $v_{\max }$ of both LipA and LipB calculated from the hydrolysis rate curves were 12.6 $\mathrm{U} \cdot \mathrm{mg}^{-1}$ and $13.3 \mathrm{U} \cdot \mathrm{mg}^{-1}, \mathrm{~K}_{0.5}$ were $1.8 \mathrm{mM}$ and $1.65 \mathrm{mM}$, respectively. The $v_{\max }$ values increased to $105 \mathrm{U} \cdot \mathrm{mg}^{-1}$ and $112 \mathrm{U} \cdot \mathrm{mg}^{-1}$ and $\mathrm{K}_{0.5}$ values decreased to $800 \mu \mathrm{M}$ and 740 $\mu \mathrm{M}$ for LipA and LipB, respectively, while the saturation curve became less sigmoidal. This result suggests that SDS and substrate bindings are distinct, and SDS micelles promote an active lipase conformation that requires less interfacial activation. Similar behavior was seen in the kinetics of sunflower phospholipase D, showing interfacial activation and sigmoidal substrate saturation profile which changed to a hyperbolic curve in the presence of SDS and Triton X-100 [32].

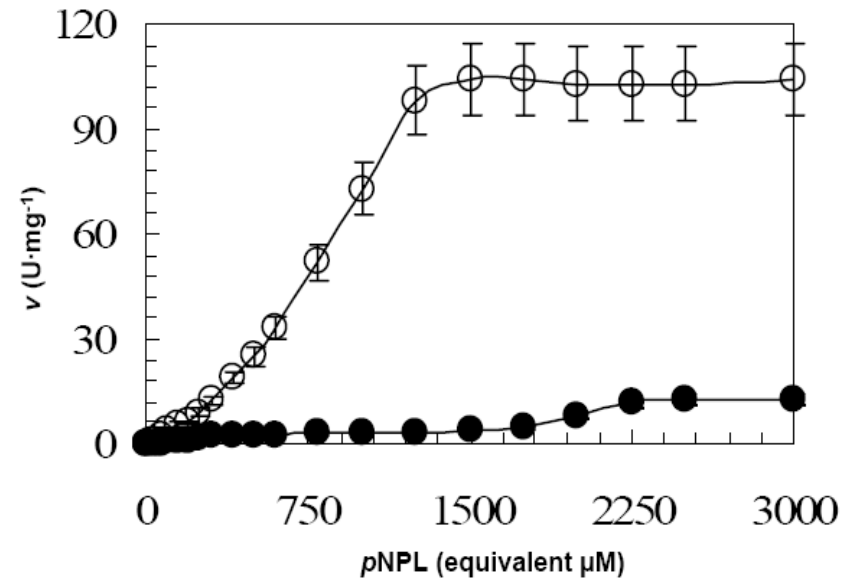

Fig. (2). The hydrolysis rate of $p$-nitrophenyl laurate by LipA in the absence $(\bullet)$ and presence of $0.2 \%$ SDS ( $\circ)$. Assays were performed as described in the materials and methods section. Each assay contained $10 \mu \mathrm{g}$ of freshly purified LipA. The assay duration was $15 \mathrm{~min}$, at the end of the assay; reactions were stopped in ice. Since LipA and LipB look very much the same, LipB was omitted for clarity. 


\section{SDS Effect on Temperature Optima}

Activity of the electrophoretically-pure lipases LipA and LipB were analyzed in the presence and absence of SDS using a 10 min assay. In the absence of SDS, LipA yielded a broad activity maximum range from $86^{\circ} \mathrm{C}$ to $96^{\circ} \mathrm{C}$ and $\mathrm{LipB}$ exhibited a biphasic curve but with a narrow maxima around $96^{\circ} \mathrm{C}$ [20]. The addition of $0.2 \%$ SDS (final concentration) lead for LipA to a more narrow maximum catalytic activity response in the range of $90^{\circ} \mathrm{C}$ to $96^{\circ} \mathrm{C}$ whereas for LipB the biphasic response disappeared and the maximum decreased from $96^{\circ} \mathrm{C}$ to $92^{\circ} \mathrm{C}$ (Fig. 3). A similar effect was observed for the lipase TIL from the temperature tolerant Thermomyces lanuginosus [25]. All of these enzymes are alkalithermophilic, more thermostable than most lipases and are activated by SDS.

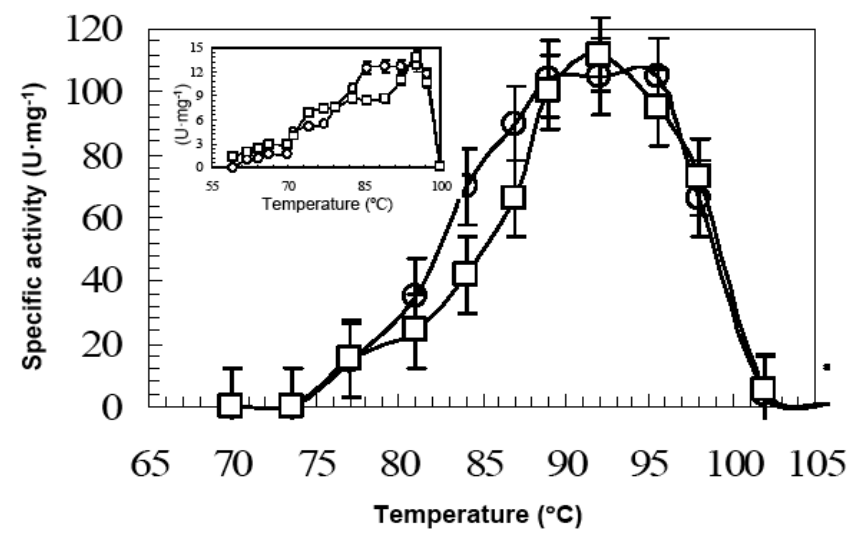

Fig. (3). Temperature activity profiles in the presence of $0.2 \%$ SDS and absence of SDS (Insert). Assays, as described in the materials and methods section, were performed in triplicates at the pH optima of LipA (०) and LipB ( $\square$ ). All data were recorded as the difference between the assays and their controls.

\section{Aggregation of LipA and LipB}

LipA and LipB form aggregates (or possibly oligomers) as shown by the elution profiles from the gel filtration chromatography (Fig. 4). When aliquots of LipA and LipB were loaded onto Superose12 column and eluted by using $20 \mathrm{mM}$ Tris buffer containing $100 \mathrm{mM} \mathrm{NaCl}$, LipA and LipB were eluted in broad peaks corresponding to a molecular mass around $280 \mathrm{kDa}$ and $400 \mathrm{kDa}$, respectively. The high molecular weight aggregates/oligomers were also observed on a gradient native PAGE (data not shown). These results suggest that LipA and LipB existed in catalytically active and soluble aggregates and both enzymes posses a considerable surface hydrophobicity. At this time, we can not distinguish between the formation of aggregation through hydrophobic interactions which is most likely, or whether the lipases form distinct oligomers.

Organic solvent and detergents were successfully used to disrupt the high molecular weight aggregation of lipases [17, $39-42]$. Using $1 \%(\mathrm{w} / \mathrm{v})$ SDS during gel filtration analysis led to the disruption of the aggregates of LipA and LipB, and the elution in one peak corresponding to the monomers of LipA and LipB (Fig. 4). When 40\% (v/v) 2-propanol was used, which also disaggregates lipases [39], a loss in activity was observed. The aggregations of lipase proteins are primarily due to hydrophobic interactions between their domains $[43,44]$. The most noticeable feature of described lipase aggregation is that all exhibited catalytic activity [16, $18,19,42]$. However, it needs to be noted that the lipase aggregation described is different from the common protein aggregation that result as a consequence of conformational alterations attributed to denaturation and hence protein inactivation $[45,46]$. It is believed that this type of protein aggregation arises from the exposure of buried hydrophobic groups in the unfolded state followed by nonspecific association of these groups [47].
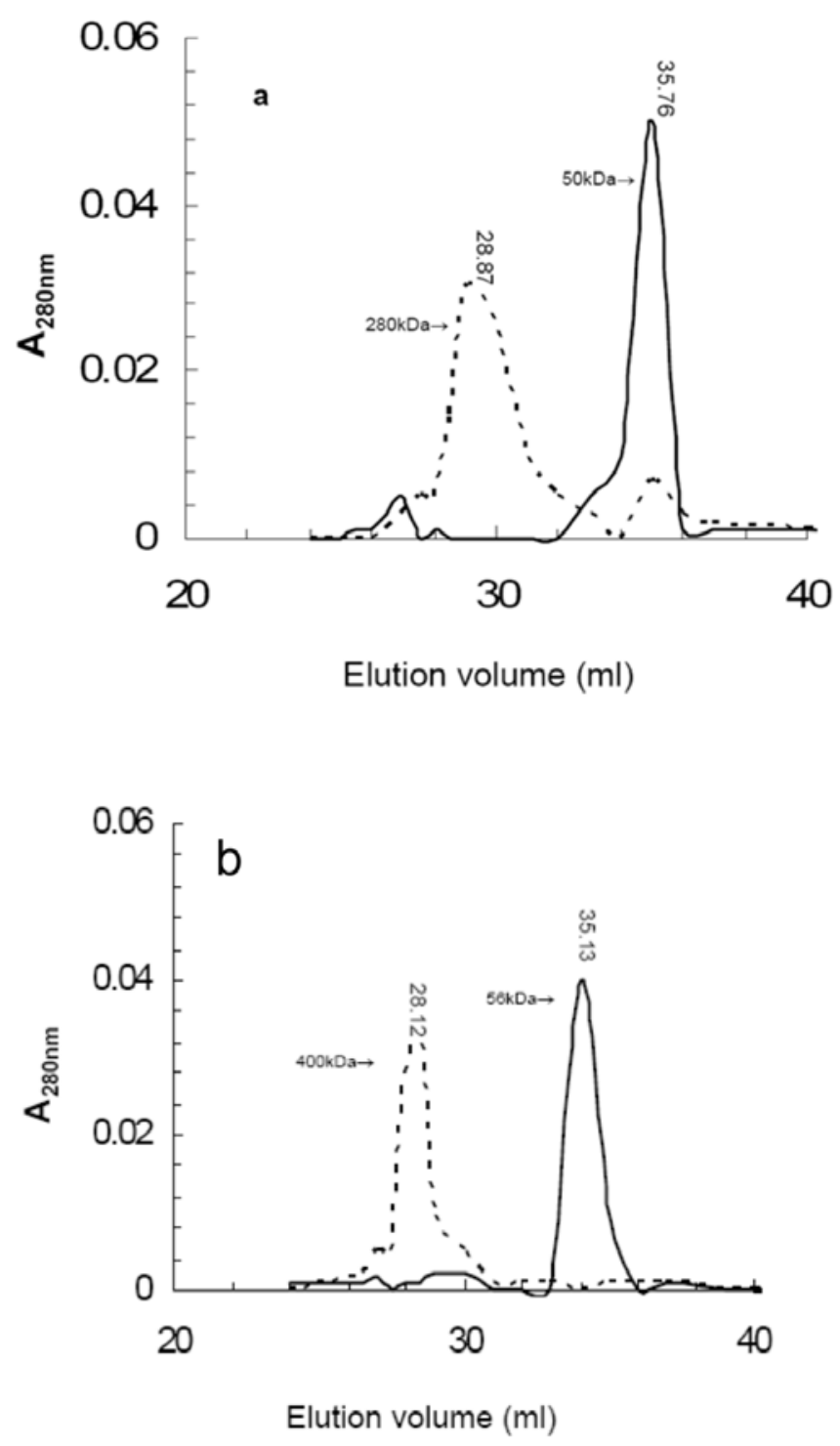

Fig. (4). The elution profiles of aggregated LipA (a) and LipB (b) after gel filtration chromatography. The first peaks (dotted line) represent aggregated enzymes eluted in the absence of SDS, the second sharper peak (solid line) represent monomeric enzyme treated and eluted with $1 \%$ SDS. The elution volume and corresponding molecular mass as calculated from standard marker is indicated on top of each peak. Elution volumes of molecular weight markers used for calculating the apparent molecular weight of the lipases were: Ferritin $(440 \mathrm{kDa}) ; 27.9 \mathrm{ml}$; bovine serum albumin (66 kDa), $35.56 \mathrm{ml}$; albumin (45 kDa), $36.8 \mathrm{ml}$; carbonic anhydrase (29kDa), $39.94 \mathrm{ml}$; and cytochrome (12.8 kDa), 41.67 $\mathrm{ml}$. 
No effect on catalytic activity was observed when LipA and LipB were disaggregated by 0.1 to $1 \%$ (v/v) Tween 20 treatment (Fig. 1). Mixed results have been reported in the literature regarding the effect of aggregation on catalytic activity of lipases. For example, Dünhaupt et al. reported a substantial increase in catalytic activity of $B$. cepacia lipase as a result of disaggregation by the addition of 2-propanol [34]. On the contrary, Rúa et al. used cholate to disaggregate $G$. thermocatenulatus lipase (BTL2), and found no effect on catalytic activity [41].

Aggregation is one of the means by which proteins can be stabilized in thermophiles [48]. Thus the thermostability of LipA and LipB were tested in the monomeric and aggregated form. As described previously [20] LipA and LipB exhibited high thermostability in the absence of detergents (LipA: $\mathrm{t}_{1 / 2} 6 \mathrm{~h}$ at $100^{\circ} \mathrm{C}, 20 \mathrm{~h}$ at $75^{\circ} \mathrm{C}$. LipB: $\mathrm{t}_{1 / 2} 2 \mathrm{~h}$ at $100^{\circ} \mathrm{C}, 24 \mathrm{~h}$ at $75^{\circ} \mathrm{C}$ at $\mathrm{pH} 8$ ). In the presence of either the ionic detergent SDS or the non ionic detergent Tween 20, LipA and LipB were in the monomeric form as determined by gel filtration. Both detergents had a profound effect on destabilizing the enzymes. The half lives of both enzymes at $75^{\circ} \mathrm{C}$ were reduced by SDS and Tween 20 to 1 and 2 hours down from 24 hours, respectively (Fig. 5). Analyzing the data from literature, no obvious relationships were found between stability at high temperature and degree of aggregation. For example, B. cepacia lipase forms aggregates and exhibits high thermostability $\left(\mathrm{t}_{1 / 2} 13 \mathrm{~h}\right.$ at $90^{\circ} \mathrm{C}$ ), [34], while $G$. thermocatenulatus lipase (BTL2) aggregated form has a half life of $30 \mathrm{~min}$ at $60^{\circ} \mathrm{C}[41,44]$.

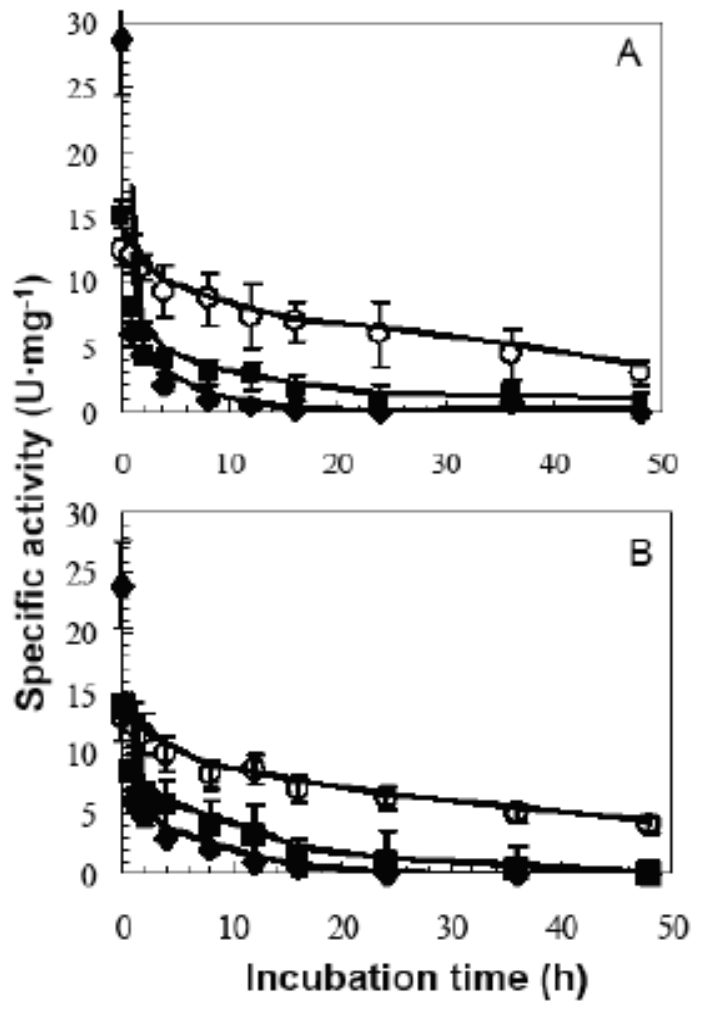

Fig. (5).Thermostability profiles of LipA (A) and LipB (B) in the absence and presence of detergents $\mathrm{A} 15 \mu \mathrm{g}$ aliquots of LipA and LipB were incubated at $75^{\circ} \mathrm{C}$ in the presence of $1 \%(\mathrm{v} / \mathrm{v})$ Tween $20(\mathbf{\bullet})$ and $1 \%(\mathrm{w} / \mathrm{v})$ SDS $(\diamond)$, and without detergent addition (control) (०). Lipase assays were conducted as described in the methods section.
Nonionic detergents normally are considered as mild detergents and that they do not interact extensively with the protein surface, whereas ionic detergents, in particular SDS, generally bind unspecifically to the protein surface, which usually lead to protein unfolding [25]. Proteins from thermophiles in general should show more stability at room temperature because they are less flexible, but as the temperature increases, proteins become more flexible and this increases the unfolding rate and decreases enzymes stability. SDS, in contrast to the nonionic detergent Tween 20 , is very reactive with LipA and LipB, enzymes became more flexible and the rate of unfolding increased. Consequently, the decrease in thermostability of LipA and LipB in the presence of $0.1 \%(\mathrm{v} / \mathrm{v})$ Tween 20 suggested that the aggregation behavior of these enzymes might play an important role in their high thermostability.

\section{ACKNOWLEDGEMENTS}

The authors are indebted for useful discussions with Drs Michael Adams, Robert Maier, Anna Karls and William B. Whitman. We are grateful to Dr. Timothy Davis for his help in growing the culture in the Fermentation Plant and in conducting flourometric measurements.

\section{NOTE ADDED IN PROOF}

Recently similar thermostable and thermophilic lipases were isolated from anaerobic bacteria: Royter, M.; Schmidt, M.; Elend, C.; Höbenreich, H.; Schäfer, T.; Bornscheuer, U.T.; Antranikian, G. Thermostable lipases from the extremophilic anaerobic bacteria Thermoannaerobacter thermohydrosulfuricus SOL1 and Caldanaerobacter subterraneus subsp. tengcongensis. Extremophiles, 2009, 13, 769-783.

\section{REFERENCES}

[1] Sarda, L.; Desnuelle, P. Action of pancreatic lipase on emulsified esters. Biochim. Biophys. Acta., 1958, 30, 513-521.

[2] Ferrato, F.; Carriere, F.; Sarda, L.; Verger, R. A critical reevaluation of the phenomenon of interfacial activation. Methods Enzymol., 1997, 286, 327-347.

[3] Jaeger, K.E.; Reetz, M.T. Microbial lipases form versatile tools for biotechnology. Trends Biotechnol., 1998, 16, 396-403.

[4] Balcão, V.; Paiva, M.; Malcata, F.X. Bioreactors with immobilized lipases: State of the art. Enzyme Microb. Technol., 1996, 18, 392 416.

[5] Bell, P.J.L.; Nevalainen, N.; Morgan, H.W.; Bergquist, P.L. Rapid cloning of thermoalkalophilic lipases from Bacillus sp. Using PCR. Biotechnol. Lett., 1999, 21, 1003-1006.

[6] Jaeger, K-E.; Dijkstra, B.W.; Reetz, M.T. Bacterial biocatalysts: molecular biology, three-dimensional structures, and biotechnological applications of lipases. Annu. Rev. Microbiol., 1999, 53, 315-351.

[7] Jaeger, K.E.; Reetz. M.T. Microbial lipases form versatile tools for biotechnology. Trends Biotechnol., 1998, 16, 396-403.

[8] Salameh, M.; Wiegel, J. Lipases from extremophiles and potential for industrial applications. Adv. Appl. Microbiol., 2007, 61, 253283.

[9] Ejima, K.; Liu, J.; Oshima, Y.; Hirooka, K.; Shimanuki, S.; Yokota, Y.; Hemmi, H.; Nakayama, T; Nishino, T. Molecular cloning and characterization of a thermostable carboxylesterase from an archaeon, Sulfolobus shibatae DSM5389: Non-linear kinetic behavior of a hormone-sensitive lipase family enzyme. $J$. Biosci. Bioeng., 2004, 98, 445-451.

[10] Fucinos, P.; Dominguez, A.; Sanroman, M.A.; Longo, M.A.; Rua, M.L.; Pastrana, L. Production of thermostable lipolytic activity by Thermus species. Biotechnol. Prog., 2005, 21, 1198-1205. 
[11] Li, H.; Zhang, X. Characterization of thermostable lipase from thermophilic Geobacillus sp. TW1. Protein Expr. Purif., 2005, 42,153-159.

[12] Pantazaki, A.A.; Pritsa, A.A.; Kyriadidis, D.A. Biotechnologically relevant enzymes from Thermus thermophilus. Appl. Microbiol. Biotechnol., 2002, 58, 1-12.

[13] Nakagawa, T.; Nakagawa, M. Solubilization. In Nonionic Surfactants; M.J. Schick, Ed.; Marcel Dekker: New York, 1966, pp. 558-603.

[14] Terstappen, G.C.; Ramelmeier, R.A.; Kula, M.R. Protein partitioning in detergent-based aqueous two-phase systems. $J$. Biotechnol., 1993, 28, 263-275.

[15] Dünhaupt, A.; Lang, S.; Wagner, F. Pseudomonas cepacia lipase: studies on aggregation, purification and on the cleavage of olive oil. Biotechnol. Lett., 1992, 14, 953-958.

[16] Rua, M.L.; Schmidt-Dannert, C.; Wahl, S.; Sprauer, A.; Schmid, R.D. Thermoalkalophilic lipase of Bacillus thermocatenulatus large-scale production, purification and properties: aggregation behaviour and its effect on activity. J. Biotechnol., 1997, 56, 89102.

[17] Bhardwaj, K.; R aju, A.; Rajasekharan, R. Identification, purification, and characterization of a thermally stable lipase from rice bran. A new member of the (phospho) lipase family. Plant Physiol., 2001, 127, 1728-1738.

[18] Lesuise, E.; Schanck, K.; Colson, C. Purification and preliminary characterization of the extracellular lipase of Bacillus subtilis 168, an extremely basic pH-tolerant enzyme. Eur. J. Biochem., 1993, 216, 155-160.

[19] Feller, G.; Thiry, M.; Arpigny, J.L.; Mergeay, M.; Gerday, C. Lipases from psychrotrophic antarctic bacteria. FEMS Micriobiol. Lett., 1990, 66, 239-244.

[20] Salameh, M.A.; Wiegel, J. Purification and characterization of two highly thermophilic alkaline lipases from Thermosyntropha lipolytica. Appl. Environ. Microbiol., 2007, 73, 7725-7731.

[21] Salameh, M.A.; Wiegel, Synthesis of fatty acid esters and diacylglycerols at elevated temperatures by alkalithermophilic lipases from Thermosyntropha lipolytica. J. Ind. Microbiol. Biotechnol., 2009, 36, 1281-1287.

[22] Winkler, U.K.; Stuckmann, M. Glycogen, hyaluronate, and some other polysaccharides greatly enhance the formation of exolipase by Serratia marcescens. J. Bacteriol., 1979, 138, 663-670.

[23] Ausubel, F.M.; Brent, R.; Kingston, R.E.; Moore, D.D.; Smith, J.A.; Seidman, J.; Struhl, K. In Current Protocols in Molecular Biology; John Wily: New York, 2001.

[24] Sambrook, J.; Fritsch, E.F.; Maniatis, T. Molecular Cloning: A Laboratory Manual; Cold Spring Harbor Laboratory Press: New York, 1989.

[25] Mogensen, J.E.; Sehgal, P.; Otzen, D.E. Activation, Inhibition, and destabilization of Thermomyces lanuginosus lipase by detergents. Biochemistry, 2005, 44, 1719-1730.

[26] Brito, R.M.; Vaz, W.L. Determination of the critical micelle concentration of surfactants using the fluore-scent probe $\mathrm{N}$-phenyl1-naphthylamine. Anal. Biochem., 1986, 152, 250-255.

[27] Chirita, N.C.; Necula, M.; Kuret, J. Anionic micelles and vesicles induce tau fibrillization in vitro. J. Biol. Chem., 2003, 278, 2564425650 .

[28] Wiegel, J. Anaerobic alkalithermophiles, a novel group of extremophiles. Extremophiles, 1998, 2, 257-267.

[29] Hermoso, J.; Pignol, D.; Kerfelec, B.; Crenon, I.; Chapus, C.; Fontecilla-Camps, J.C. Lipase activation by nonionic detergents. The crystal structure of the porcine lipase-colipase-tetraethylene glycol monooctyl ether complex. J. Biol. Chem., 1996, 271, 1800718016.

[30] Helistö, P.; Korpela, T. Effect of detergents on activity of microbial lipases as measured by the nitrophenyl alkanoate esters method. Enzyme Microb. Technol., 1998, 23, 113-117.
[31] Misiorowski, R.L.; Wells, M.A. The activity of phospholipase A2 in reversed micelles of phosphatidylcholine in diethyl ether: Effect of water and cat ions. Biochemistry, 1974, 13, 4921-4927.

[32] Abousalham, A.; Nari, J.; Teissere, M.; Ferte, N.; Noat, G.; Verger, R. Study of fatty acid specificity of sunflower phospholipase D using detergent/phospholipid micelles. Eur. J. Biochem., 1997, 248, 374-379.

[33] Lai, D.T.; O'Connor, C.J. Synergistic effects of surfactants on kid pregastric lipase catalyzed hydrolysis reactions. Langmuir, 2000, 16, $115-121$.

[34] Otzen, D.E. Protein unfolding in detergents: Effect of micelle structure, ionic strength, $\mathrm{pH}$, and temperature. Biophys. J., 2002, 83, 2219-2230.

[35] Ejima, K.; Liu, J.; Oshima, Y.; Hirooka, K.; Shimanuki, S.; Yokota, Y.; Hemmi, H.; Nakayama, T.; Nishino, T. Molecular cloning and characterization of a thermostable carboxylesterase from an archaeon, Sulfolobus shibatae DSM5389: Non-linear kinetic behavior of a hormone-sensitive lipase family enzyme. $J$. Biosci. Bioeng., 2004, 98, 445-451.

[36] Cajal, Y.; Svendsen, A.; Girona, V.; Patkar, S.A.; Alsina, M.A. Interfacial control of lid opening in Thermomyces lanuginosa lipase. Biochemistry, 2000, 39, 413-423.

[37] Yapoudjian, S., Ivanova, M.G.; Brzozowski, A.M.; Patkar, S.A.; Vind, J.; Svendsen, A.; Verger, R. Binding of Thermomyces (Humicola) lanuginosa lipase to the mixed micelles of cis-parinaric acid/NaTDC. Eur. J. Biochem., 2002, 269, 1613-1621.

[38] Maylie, M.F.; Charles, M.; Desnuelle, P. Action of organophosphates and sulfonyl halides on porcine pancreatic lipase. Biochim. Biophys. Acta, 1972, 276, 162-175.

[39] Dünhaupt, A.; Lang, S.; Wagner, F. Pseudomonas cepacia lipase: studies on aggregation, purification and on the cleavage of olive oil. Biotechnol. Lett., 1992, 14, 953-958.

[40] Graupner, M.; Haalck, L.; Spener, F.; Lindner, H.; Glatter, O.; Paltauf, F.; Hermetter, A. Molecular dynamics of microbial lipases as determined from their intrinsic tryptophan fluorescenc. Biophys. J., 1999, 77, 493-504.

[41] Rua, M.L.; Schmidt-Dannert, C.; Wahl, S.; Sprauer, A.; Schmid, R.D. Thermoalkalophilic lipase of Bacillus thermocatenulatus large-scale production, purification and properties: aggregation behaviour and its effect on activity. J. Biotechnol., 1997, 56, 89102.

[42] Schlieben, N.H.; Niefind, K.; Schomburg, D.; Expression, purification, and aggregation studies of His-tagged thermoalkalophilic lipase from Bacillus thermocatenulatus. Protein Expr. Purif., 2004, 34,103-110.

[43] Ali, M.H.; Imperiali, B. Protein oligomerization: how and why Bioorg. Med. Chem., 2005, 13, 5013-20.

[44] Schmidt-Dannert, C.; Sztajer, H.; Stocklein, W.; Menge, U.; Schmid, R.D. Screening, purification and properties of a thermophilic lipase from Bacillus thermocatenulatus. Biochim. Biophys. Acta, 1994, 1214, 43-53.

[45] Joly, M. A Physico-chemical Approach to the Denaturation of Proteins, Academic Press: London, 1965.

[46] Remmele, Jr. R.L.; Zhang-van Enk, J.; Dharmavaram, V.; Balaban, D.; Durst, M.; Shoshitaishvili, A.; Rand, H. Scan-rate-dependent melting transitions of interleukin-1 receptor (type II): elucidation of meaningful thermodynamic and kinetic parameters of aggregation acquired from DSC simulations. J. Am. Chem. Soc., 2005, 127, 8328-8339.

[47] Remmele, Jr. R.L.; Bhat, S.D.; Phan, D.H.; Gombotz, W.R. Minimization of recombinant human Flt3 ligand aggregation at the $T_{\mathrm{m}}$ plateau: A matter of thermal reversibility. Biochemistry, 1999, $38,5241-5247$.

[48] Walden, H.; Bell, G.S.; Russell, R.J.M.; Siebers, B.; Hensel, R.; Taylor, G.L. Tiny TIM: a small, tetrameric, hyperthermostable triosephosphate isomerase. J. Mol. Biol., 2001, 306, 745-757. 